\title{
Quantitative Exploratory Analysis of the Variation in Hemoglobin between the Third Trimester of Pregnancy and Postpartum in a Vulnerable Population in VRAEM - Perú
}

\author{
Lina Cardenás-Pineda ${ }^{1}$, Raquel Aronés-Cárdenas ${ }^{2}$, Gabriela Ordoñez- Ccora ${ }^{3}$ \\ Mariza Cárdenas ${ }^{4}$, Doris Quispe ${ }^{5}$, Jenny Mendoza ${ }^{6}$, Alicia Alva Mantari ${ }^{7}$ \\ Universidad Nacional de Huancavelica, Huancavelica, Perú ${ }^{1,3,4,5,6}$ \\ Hospital de Apoyo San Francisco, VRAEM, Perú ${ }^{2}$ \\ Image Processing Research Laboratory (INTI-Lab), Universidad de Ciencias y Humanidades, Lima, Perú ${ }^{7}$
}

\begin{abstract}
The study is based on determining the difference in hemoglobin in the third trimester of pregnancy and the immediate puerperium of childbirths attended at the Hospital de Apoyo San Francisco, during 2018, located in the VRAEM area, a vulnerable area due to the level of poverty and exposure of the area. The type of the research was observational, retrospective longitudinal section in related samples, the study has the descriptive level, it has a sample of 107 childbirths, 55 vaginal and 52 cesarean, the documentary review technique was used, the data was analyzed with the statistical program " $R$ " for data analysis, the non-parametric test Wilcoxon was used. Results: a difference of $1.52 \mathrm{~g} / \mathrm{dl}$ has been found between hemoglobin of the third trimester of pregnancy $11.89 \mathrm{~g} / \mathrm{dl}$ and immediate puerperium $10.37 \mathrm{~g} / \mathrm{dl}$; when analyzing the difference in vaginal childbirths, hemoglobin in the third trimester was found at 11.90 $\mathrm{g} / \mathrm{dl}$ and the immediate puerperium was $10.65 \mathrm{~g} / \mathrm{dl}$, and in cesarean childbirths was $11.94 \mathrm{~g} / \mathrm{dl}$ in the third trimester of pregnancy and $10.14 \mathrm{~g} / \mathrm{dl}$ in the immediate puerperium, finding differences of $1.52 \mathrm{~g} / \mathrm{dl}$ in vaginal childbirths and $1.8 \mathrm{~g} / \mathrm{dl}$ in cesarean. Conclusion, there is a significant difference in hemoglobin in the third trimester and postpartum at a p-value of 0.05, being higher in cesarean childbirths; the average postpartum hemoglobin denotes anemia despite the fact that the blood losses were within normal parameters, which indicates that it must achieve that the pregnant women reach the third trimester of pregnancy with at least $13 \mathrm{~g} / \mathrm{dl}$ of hemoglobin.
\end{abstract}

Keywords-Hemoglobin; pregnant; puerperium; childbirth; cesarean; anemia; vulnerable area

\section{INTRODUCTION}

The Valle del Río Apurímac, Ene y Mantaro (VRAEM) is a place targeted by the Peruvian government with the aim of reducing poor indicators in health, education and development; anemia is a global problem, reporting at the Ayacucho region level in $22 \%$, higher figures are assumed in the population studied due to the characteristics indicated, it was found $58.5 \%$ in 2011 . Anemia is clinically defined as a decrease in useful hemoglobin below the physiological levels determined for age, gender, pregnancy and residence [1], the WHO defines anemia in pregnancy as hemoglobin less than $11 \mathrm{mg} / \mathrm{dl}$ in the first and third trimester [2] and considers blood loss up to $500 \mathrm{ml}$ in vaginal and $1000 \mathrm{ml}$ in cesarean childbirth to be physiological[3], higher than the indicated figures is considered bleeding. The calculation of blood loss is imprecise [1][4], however, the evaluation of hemoglobin before and after childbirth gives valuable information on the hemodynamic status of the mother, decreases greater than 2.9 gr\% in hemoglobin, it indicates that the mother is entering a bleeding problem.

Determining the variation in hemoglobin in the third trimester and the postpartum period allowed to analyze the hemodynamic state with which the pregnant woman enters to childbirth, whether the blood loss in childbirth is in physiological standards and how the mother is in the immediate postpartum period [5]. Important data to focus prenatal care in the prevention and treatment of anemia and prepare the pregnant woman to face the aforementioned processes, without compromising her health [6].

\section{- Hemoglobin}

It is a complex compound of proteins and iron found in the red blood cell or erythrocytes membrane, each one can have 200 to 300 hemoglobin molecules, it is color red, its molecular weight is $64 \mathrm{kd}$, and it has 4 heme groups and each heme group can transport an oxygen molecule [7]. The binding and release of oxygen to hemoglobin depends on the partial pressure of this gas; high in the lungs, where atmospheric air enters, low in tissues where cellular respiration tirelessly consumes it in the mitochondria. In arterial blood, approximately $98 \%$ of the heme groups of hemoglobin carry bound oxygen, while in venous blood, after transfer to cells, still a third of them carry it, they are still oxyhemoglobin. Despite this relatively poor performance, it is more than enough to meet the body's needs [8].

Hemoglobin is a protein found in erythrocytes whose function is to transport oxygen to the tissues, however this estimate does not constitute a particularly sensitive indicator of anemia, because the contribution of oxygen to the tissues depends on the concentration of hemoglobin, the ability of hemoglobin to fix oxygen and blood flow through these 
tissues, however hemoglobin in blood has been used since the test is simple, inexpensive [9].

\section{- Hemoglobin Physiology during Pregnancy}

The volume of the blood plasma increases, producing hemodilution (there is more fluid and the blood becomes more fluid, less dense, to be able to pass more easily to the placenta and vice versa). When this phenomenon occurs in blood tests, a decrease in hemoglobin is seen despite the fact that there is actually more hemoglobin. That is, the woman has more hemoglobin than before she was pregnant, but with increasing plasma volume there is a lower concentration [2].

Iron needs in pregnancy increase from $1-2.5 \mathrm{mg} /$ day in the beginning to $6.5 \mathrm{mg}$ in the end of pregnancy. This may suggest that they need to ingest more iron, however, a balanced diet is sufficient since this increase in requirements is compensated by a greater absorption capacity of iron. At 12 weeks of gestation, the absorption capacity increases up to $7 \%$ and at week 36, it reaches an incredible of $66 \%$ [10].

There are changes that occur as the pregnancy progresses, which involve anatomical and physiological modifications, including some hematological changes: such as the expansion of blood volume with an average of $50 \%$ during the first and second trimester; expanding more rapidly from 28 to 35 weeks of gestation, followed by a pregnancy plateau during the last weeks; achieving an approximate increase of $1500 \mathrm{ml}$ in the single pregnancy and $2000 \mathrm{ml}$ in twin pregnancy, equivalent to $40 \%$ of the plasma volume in the non-pregnant state in cases of single pregnancy and more than $50 \%$ in multiple pregnancies; the increased blood volume results from increased plasma and red blood cells. During pregnancy, the production of erythropoietin is increased, being an important stimulus for medullary erythropoiesis; erythropoiesis is also influenced by the placental lactogen, is increased by progesterone and inhibited by estrogens; the increase of the erythrocytes will be only $18 \%$ if no iron supplementation is used, and instead it is $32 \%$ if supplemental iron is administered [11].

\section{A. Difference in Hemoglobin of Pregnancy and Postpartum}

Rubio, et al [11], presents a research "Concordancia entre la estimación visual y la medición del volumen recolectado en una bolsa del sangrado intraparto en mujeres con parto normal en Bogotá, Colombia, 2006" when making a review finds various difficulties in the quantification of blood loss, which made it necessary to evaluate the difference in hemoglobin, finding an average of $1.2 \mathrm{gr} / \mathrm{dl}$. Factors linked to blood loss during childbirth. In physiological terms, they are due to placental abruption, episiotomy and loss of lochia in the immediate puerperium [12].

\section{B. Anemia in Pregnancy}

The WHO has defined anemia in pregnancy as hemoglobin less than $11 \mathrm{mg} / \mathrm{dl}$ in the first and third trimester, in the second trimester anemia is considered when it is below $10.5 \mathrm{~g} / \mathrm{dl}$, the lowest point of hemoglobin is typically measured between 28 to 36 weeks [13]. From the physiological point of view, anemia is called when the mass of circulating red blood cells is insufficient to maintain adequate oxygen transport to the tissues, causing tissue hypoxia; however clinically it is defined as a decrease in useful hemoglobin below the physiological levels determined for age, gender, pregnancy and residence [14]. [14]:

Also according to its severity, it is classified as follows

a) Mild anemia: Hemoglobin 10.1 to $10.9 \mathrm{~g} / \mathrm{dl}$, Hematocrit 33-27\%.

b) Moderate anemia: Hemoglobin 7.1 at $10 \mathrm{~g} / \mathrm{dl}$. Hematocrit 26-21\%. $<21 \%$.

c) Severe anemia: Hemoglobin $<7 \mathrm{~g} / \mathrm{dl}$, Hematocrit

The most common causes of anemia include iron deficiency, folate deficiency, vitamin B12 deficiency, bone marrow suppression, hemolytic disease, chronic blood loss, and underlying malignancies. Iron deficiency anemia being the most common cause of anemia in pregnant women [8].

Maternal nutritional status should not be considered exclusively as the nutritional status in the gestational period but as a result of every life process that begins intrauterine, that is, the phases of rapid growth are during intrauterine life, childhood and adolescence, moments in which the energy, protein, mineral and vitamin requirements are high. That is why, children and pregnant women, exposed to poor diets and repeated infections, easily fall into the vicious circle that leads to malnutrition [15].

There are several factors that can predict the nutritional status of the newborn, as well as the complications of the mother during pregnancy and postpartum, being easy to handle and identify: age, weight, height, maternal hemoglobin, the same ones that determine the risks obstetric as well as the nutritional status and malnutrition of the pregnant mother that is directly related to low birth weight or underweight [16].

\section{Postpartum Anemia}

The definition of anemia in the puerperium has not yet been agreed, the technical norm for the control and reduction of anemia in Peru, it considers anemia when $\mathrm{Hb}<12 \mathrm{~g} / \mathrm{dl}$. On the other hand, in a study carried out in Berlin, by Zeng L. Dibley, it was observed that the distribution of postpartum $\mathrm{Hb}$ and its percentiles leaned to a mean of $11.0 \mathrm{~g} / \mathrm{dl}$ and a median of $11.2 \mathrm{~g} / \mathrm{dl}$. Furthermore, about one in five women were anemic $(\mathrm{Hb}<10 \mathrm{~g} / \mathrm{dl})$, and one in 30 developed severe anemia $(\mathrm{Hb}<8 \mathrm{~g} / \mathrm{dl})$ on the second day after childbirth [17].

The consequences of postpartum anemia describe associations between it and the increased prevalence of tiredness, respiratory distress, palpitations and infections, especially those of the urinary tract. In addition, emotional instability and increased risk of postpartum depression are described. This set of symptoms and states could difficult the interaction between mother and child, interfering with their emotional interaction [18].

\section{Risk Factors}

a) Age of the pregnant woman: The age limit that is considered adequate for the attainment of pregnancy has been changing passing the years and there is no unanimity in this 
regard. Currently, this limit is set at 35 years old, although there is no lack of research that place it at 40 and even 44 years old. In this study, the 35-year criterion was followed according to the Sociedad Española de Ginecología y Obstetricia (SEGO) [19].

b) Parity: Refers to the number of pregnancies of a woman who has given birth, a product older than 20 weeks, weighing more than 500 gr., a height mor than $25 \mathrm{~cm}$., alive or dead, regardless of the placental outlet of the umbilical cord section [6].

c) Multiple pregnancy: Multiple gestation means that two or more products are developed simultaneously. Multiple pregnancies carry a higher risk of fetal malformations and a twin-twin transfusion syndrome. Also, maternal complications are increased. In a study by Walker MC. found that, compared to singleton pregnancies, the risks of pre-eclampsia, postpartum hemorrhage, and maternal death increased two or more times [20].

d) Childbirth type: Physiological process that ends the pregnancy, determining that the product and its annexes leave the uterus and go outside. For the present study, vaginal or eutocic Childbirth was considered, defining vaginal as spontaneous onset and completion with the expulsion of the product and its annexes, between 37 and 42 weeks of gestation that requires or does not require the active intervention of a qualified medical professional, without the need for an abdominal culmination. A cesarean childbirth was considered to be one that required the intervention of a qualified medical professional for its completion by the abdominal via [4].

e) Third trimester hemorrhage: Obstetric hemorrhage is still a potential cause of maternal and fetal morbidity and mortality. It happens at any time during pregnancy, it is cause for concern and alarm. Severe vaginal bleeding is rare before 24 weeks, and when it occurs, treatment of the mother is a priority. However, the chances of fetal survival in the third trimester are significant. Third trimester hemorrhages appear in $4 \%$ of all pregnancies. They may be due to some detachment of a placenta inserted in the vicinity of the Internal Cervical Orifice (ICO), that is, a Previous Placenta (PP), or due to detachment of a placenta inserted in any other part of the uterine cavity, that is, a Placental Abruption (PA). In very rare cases, bleeding may be the result of the venous insertion of the umbilical cord (vasa previa) with hemorrhage of fetal origin. Postpartum hemorrhage is one of the most feared obstetric complications and is one of the top three causes of maternal mortality in the world. It is universally defined as blood loss of more than $500 \mathrm{ml}$ after vaginal childbirth or $1,000 \mathrm{ml}$ after cesarean. Early Postpartum Hemorrhage (EPH) is one that occurs during the first 24 hours after childbirth and is generally the most severe. The causes of EPH include uterine atony, trauma/laceration, retention of products of conception and coagulation disturbances, the most frequent being atony [3].

f) Instructional grade: It is defined as the highest grade of studies that the patient achieved, regardless of completion or in progress, for the present study was systematized as follows [14].

g) Prenatal control: It is the set of health activities that pregnant women receive during pregnancy. Medical care for pregnant women is important to ensure a healthy pregnancy and includes regular checkups and prenatal tests. This type of care is usually started when the woman discovers that she is pregnant [21].

h) Obstetric comorbidities: It is defined as the coexistence in the same individual of a pathological state, during pregnancy and childbirth, including for example premature rupture of the membranes, uterine placental insufficiency, urinary tract infection, premature detachment of the placenta, hypertensive disease of the pregnancy, oligohydramnios, polyhydramnios, etc. [21].

\section{E. Variables}

The main variable is maternal hemoglobin. This variable was collected at 2 specific times and is represented by 2 values.

a) Third trimester hemoglobin: It is the last hemoglobin control that is collected to all pregnant women who enter the health center in childbirth.

b) Immediate puerperium hemoglobin: It is the hemoglobin control within the first 24 hours after childbirth.

Other variables explained in Table I were included.

TABLE I. MOOdLE TECHNICAL CHARACTERISTICS

\begin{tabular}{|c|c|c|c|c|c|c|}
\hline Variable & Conceptual Definition & Operational Definition & Indicators & ITEM & Value & Variable \\
\hline \multirow{5}{*}{$\begin{array}{l}\text { Maternal } \\
\text { Hemoglobin }\end{array}$} & \multirow{5}{*}{$\begin{array}{l}\text { Hemoglobin is a } \\
\text { component of red blood } \\
\text { cells and its main } \\
\text { function is to transport } \\
\text { oxygen from the } \\
\text { respiratory organs to } \\
\text { the tissues of the body. }\end{array}$} & \multirow{5}{*}{$\begin{array}{l}\text { It is the maternal } \\
\text { hemoglobin identified } \\
\text { the closest to delivery } \\
\text { and on the first day } \\
\text { after delivery. }\end{array}$} & Age & Age in years that labor occurs & Numerical & Discrete numeric \\
\hline & & & Parity & $\begin{array}{l}\text { How many births did she has } \\
\text { before this? }\end{array}$ & Numerical & Discrete numeric \\
\hline & & & $\begin{array}{l}\text { Childbirth } \\
\text { Type }\end{array}$ & What was the childbirth type? & $\begin{array}{l}\text { Vaginal (1) } \\
\text { Cesarean (2) }\end{array}$ & $\begin{array}{l}\text { Categorical } \\
\text { Nominal }\end{array}$ \\
\hline & & & $\begin{array}{l}\text { Third } \\
\text { Trimester } \\
\text { Hemoglobin }\end{array}$ & $\begin{array}{l}\text { How much hemoglobin } \\
\text { registers in her last control } \\
\text { during pregnancy? }\end{array}$ & $\begin{array}{l}\text { Numeric in } \\
\mathrm{g} / \mathrm{dl}\end{array}$ & $\begin{array}{l}\text { Numeric } \\
\text { Continuous }\end{array}$ \\
\hline & & & $\begin{array}{l}\text { Puerperium } \\
\text { hemoglobin }\end{array}$ & $\begin{array}{l}\text { How much hemoglobin } \\
\text { registers in the control within } \\
24 \text { hours postpartum? }\end{array}$ & $\begin{array}{l}\text { Numeric in } \\
\mathrm{g} / \mathrm{dl}\end{array}$ & $\begin{array}{l}\text { Numeric } \\
\text { Continuous }\end{array}$ \\
\hline
\end{tabular}




\section{METHODOLOGY}

\section{A. Scope of Study}

This study was carried out at the Hospital de Apoyo San Francisco, it is a level II - 1 hospital (Fig. 1), which welcomes users from the VRAEM area (Ayacucho, Cusco and Junín); being the priority the attention of children, pregnant mothers and other cases of Emergency, that are referred daily to this Hospital. It is located on the left of the Apurímac river, in the San Francisco district of the La Mar province, Ayacucho region, it is part of the Apurímac River Valley and Ene VRAEM. The territorial surface is $265.73 \mathrm{~km}^{2}$, the capital of the district is located at an altitude of 600 m.a.s.l. (meters above sea level), $12^{\circ} 37^{\prime} 50^{\prime \prime}$ Longitude West and $73^{\circ} 47^{\prime} 40^{\prime \prime}$ South Latitude, the altitudes has a descend approximately from 4000 m.a.s.l. since 600 m.a.s.l. the limits are by the east with the Apurimac River, by the west with the Huanta district, by the north with the Sivia district, by the south with the Santa Rosa district (Fig. 2). It has a population of approximately 8,607 inhabitants, distributed in 43 populated centers, it has a population density of 32.4 inhab / $\mathrm{Km}^{2}$. It has 03 Municipalities of smaller Populated Centers. The Hospital San Francisco is a referential establishment that also cares for the population from Ayacucho, Junín and Cuzco areas, as well as a highly migratory area due to socio-economic and political conditions, the priority activity is agriculture, especially the coca cultivation.

For the present study, important data were also taken from the different systems of registration of patient care, one of them is the Nutritional Assessment System of the pregnant woman (NAS), which shows that approximately $80 \%$ of pregnant women have some degree of anemia, especially pregnant women from native communities who have a food deficit whose consumption is only based on carbohydrates (cassava and banana).

\section{B. Design and Population}

The type of research was observational, a secondary source was used for the collection of information, so is classified as a retrospective longitudinal section of a related sample, because the hemoglobin data is collected in the third trimester and in the immediate postpartum of the pregnancy of same pregnant woman [22].

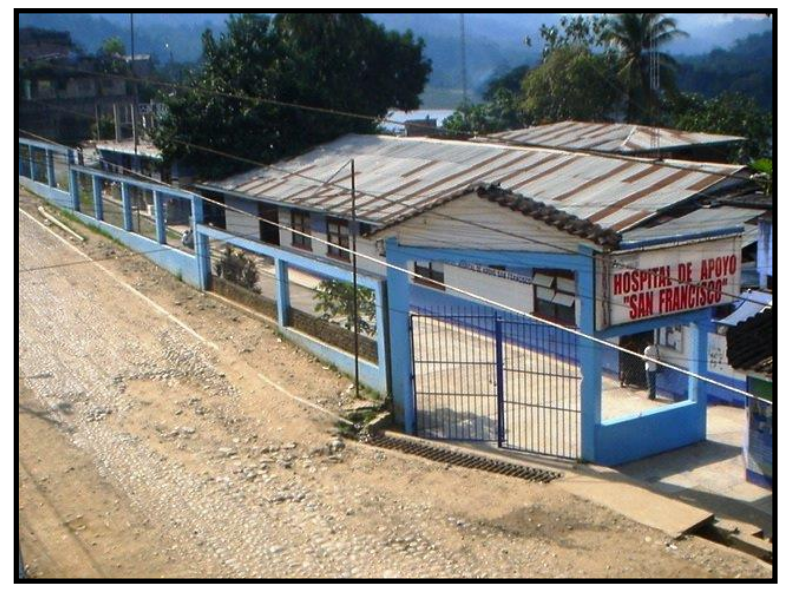

Fig. 1. Hospital de Apoyo "San Francisco"-VRAEM - Perú.

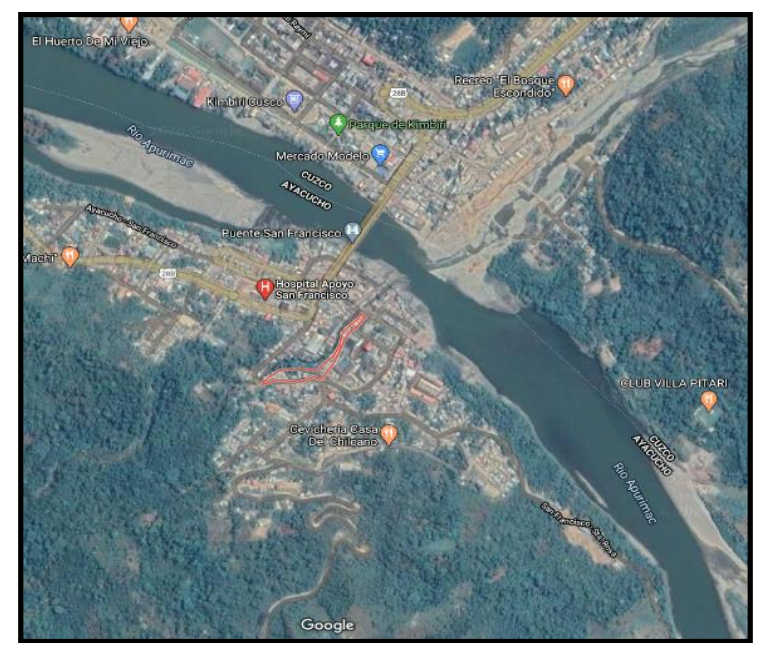

Fig. 2. Geolocation of the Hospital de Apoyo "San Francisco" - VRAEM Perú.

When the researchers collect the information of the object of study as it happens in reality and is limited only to observe and describe the phenomenon, the descriptive level is attributed to it, in this case the maternal hemoglobin is studied at two crucial moments such as when it ends pregnancy and immediate postpartum [23].

1) Population: Childbirths attended at the Hospital de Apoyo San Francisco during the period 2018. A total of 658, of them 375 vaginal and 283 cesareans.

2) Sample size: The sample size of the total population of the Medical center was determined, stratifying the sample according to the childbirth type. The sample obtained is given as follows in Table II.

The Analysis Unit is each pregnant woman whose childbirth was attended at the Hospital de Apoyo San Francisco.

Sampling is serial random probability. Exclusion criteria were pregnant women without a record of hemoglobin control in the third trimester and/or in the immediate puerperium. Pregnant women with hemorrhagic complications in pregnancy, childbirth or the puerperium and those whose clinical histories in legal proceedings will also be excluded.

\section{Data Collection Techniques and Instruments}

The technique used was documentary analysis. For the review of medical records and laboratory results, an observation sheet was used as an instrument.

\section{Data Processing and Analysis Techniques}

The statistical program " $R$ " was applied for data analysis.

TABLE II. HEMOGLOBIN OF THE THIRD TRIMESTER OF PREGNANCY AND THE IMMEDIATE PUERPERIUM OF CESAREAN CHILDBIRTHS ATTENDED AT THE HOSPITAL DE APOYO SAN FRANCISCO, 2018

\begin{tabular}{|l|l|l|}
\hline Childbirth Type & Population & Sample \\
\hline Vaginal & 375 & 55 \\
\hline Cesarean & 283 & 52 \\
\hline TOTAL & 658 & 107 \\
\hline
\end{tabular}


First, it was evaluated if the age, parity and childbirth type influence the difference in hemoglobin from the third trimester to the immediate postpartum period, finding significant difference only in the childbirth type. Based on the suspicion of atypical data, their validation is made through the KOLMOGOROV - SMIRNOV test, if the data does not meet the normality test, the Wilcoxon non-parametric test is used, a $\mathrm{p}$ value of 0.05 .

\section{RESULTS}

The study was carried out in 107 pregnant women, whose childbirths happened at the Hospital de San Franciso in 2018, a hospital located in the VRAEM, it is important to know the characteristics of maternal hemoglobin during the pregnancy to the immediate puerperium. For this, hemoglobin was taken during the third trimester of pregnancy and then in the immediate puerperium, which is routine for all women treated at the Hospital. As part of the study, the variables age, parity and type of delivery were collected; from a statistical analysis it was determined that the only significant difference in hemoglobin was the Chilbirth type, as we see in Table III.

Table IV shows the average hemoglobin of the third trimester at $11.89 \mathrm{~g} / \mathrm{dl}$, which means that pregnant women enter to the childbirth with the indicated value, marking a significant difference with respect to the hemoglobin of the immediate puerperium, which was recorded on average at $10.37 \mathrm{~g} / \mathrm{dl}$ with a $\mathrm{P}<0.05$. The difference between both averages is $1.52 \mathrm{~g} / \mathrm{dl}$.

Table $\mathrm{V}$ shows the average hemoglobin of the third trimester of pregnancy at $11.90 \mathrm{~g} / \mathrm{dl}$, and the average was recorded at $10.65 \mathrm{~g} / \mathrm{dl}$ in the immediate puerperium, the difference is $1.25 \mathrm{~g} / \mathrm{dl}$, it is statistically significant, with a $\mathrm{P}<0.05$.

Table VI shows the average hemoglobin of the third trimester of pregnancy at $11.94 \mathrm{~g} / \mathrm{dl}$, and the average was recorded at $10.14 \mathrm{~g} / \mathrm{dl}$ in the immediate puerperium, the difference calculated is $1.8 \mathrm{~g} / \mathrm{dl}$, showing a significant difference between both with a $\mathrm{P}<0.05$. Therefore, the hypothesis is accepted.

TABLE III. VARIABLES Y SIGNIFICANCE

\begin{tabular}{|l|l|}
\hline Feature & P- Value Statiscal \\
\hline Age & 0.32673 \\
\hline Parity & 0.1114 \\
\hline Childbirth Type & 0.00097 \\
\hline
\end{tabular}

TABLE IV. HEMOGLOBIN OF THE THIRD TRIMESTER OF PREGNANCY AND THE IMMEDIATE PUERPERIUM OF CHILDBIRTH ATTENDED AT THE HOSPITAL DE APOYO SAN FRANCISCO, 2018

\begin{tabular}{|l|l|l|l|}
\hline Descriptive & $\begin{array}{l}\text { Hemoglobin III } \\
\text { Trimester (g/dl) }\end{array}$ & $\begin{array}{l}\text { Hemoglobin } \\
\text { Puerperium (g/dl) }\end{array}$ & $\begin{array}{l}\text { Average } \\
\text { Difference } \\
\text { (g/dl) }\end{array}$ \\
\hline Group Size (n) & 107 & 107 & \\
\hline Average (X) & $11.89^{\mathrm{a}}$ & $10.37^{\mathrm{b}}$ & 1.52 \\
\hline $\begin{array}{l}\text { Typical Error } \\
\text { (TE) }\end{array}$ & 0.09 & 0.12 & \\
\hline
\end{tabular}

TABLE V. HEMOGLOBIN OF THE THIRD TRIMESTER OF PREGNANCY AND THE IMMEDIATE PUERPERIUM OF CAESAREAN CHILDBIRTHS ATTENDED AT HOSPITAL DE APOYO SAN FRANCISCO, 2018

\begin{tabular}{|l|l|l|l|}
\hline Descriptive & $\begin{array}{l}\text { Hemoglobin } \\
\text { III Trimester } \\
\text { (g/dl) }\end{array}$ & $\begin{array}{l}\text { Hemoglobin } \\
\text { Puerperium (g/dl) }\end{array}$ & $\begin{array}{l}\text { Average } \\
\text { Difference } \\
\text { (g/dl) }\end{array}$ \\
\hline Group Size (n) & 53 & 53 & \\
\hline Average (X) & $11.90^{\mathrm{a}}$ & $10.65^{\mathrm{b}}$ & 1.25 \\
\hline Typical Error (TE) & 0.12 & 0.15 & \\
\hline
\end{tabular}

\section{DISCUSSION}

The quantification of maternal hemoglobin in the third trimester or when the pregnant woman begins the childbirth, is a reference of the hemodynamic situation which the pregnant enters in the childbirth and the postpartum control, it shows us her state having gone through the wonderful process of childbirth, which is often not so good, since actually, it does not have an exact loss quantification [4], the measurement of hemoglobin in the pre and postpartum are important data to evaluate the postpartum woman in her hemodynamic state, fundamental procedure because bleeding is the main cause of maternal mortality, therefore any loss that leads to a situation of anemia must be treated immediately.

The calculated average of hemoglobin in the third trimester is $11.89 \mathrm{~g} / \mathrm{dl}$, lower than that reported by Quispe [24] which was $12.7 \mathrm{~g} / \mathrm{dl}$ in the city of Puno in 2016, it could be due to the geographical location that is so different from both studies (jungle and highlands); also in the scope of study according to NAS, $80 \%$ of pregnant women have some degree of anemia; it is important to reflect that the hemoglobin of the third trimester of the pregnant woman does not support the physiological blood loss of childbirth, as a consequence, it is decreased in the postpartum period falling to $10.37 \mathrm{~g} / \mathrm{dl}$, the value corresponds to a mild anemia, this difference is statistically significant at a p-value of 0.05 , the decrease occurred in $1.52 \mathrm{~g} / \mathrm{dl}$, a value that is located in the 50th percentile due to the table of quantification of blood loss made by Rubio [11], although it is true that the difference in hemoglobin is not yet classified as a considerable loss that could be a hemorrhage. Hemoglobin in the immediate puerperium is a figure that is considered mild anemia [14], this is due to the hemoglobin in the third trimester is also not optimal to face childbirth; this finding leads us to the need to strengthen the development of anemia prevention strategies in pregnancy in accordance with the current national plan [22], in such a way that the pregnant woman enters to childbirth with a reserve that can make blood loss bearable than physiologically that happens in childbirth and the immediate puerperium.

TABLE VI. HEMOGLOBIN OF THE THIRD TRIMESTER OF PREGNANCY AND THE IMMEDIATE PUERPERIUM OF CESAREAN CHILDBIRTH ATTENDED AT THE HoSPITAL DE APOYO SAN FRANCISCO, 2018

\begin{tabular}{|l|l|l|l|}
\hline Descriptive & $\begin{array}{l}\text { Hemoglobin III } \\
\text { Trimester }(\mathbf{g} / \mathbf{d l})\end{array}$ & $\begin{array}{l}\text { Hemoglobin } \\
\text { Puerperium } \\
\text { (g/dl) }\end{array}$ & $\begin{array}{l}\text { Average } \\
\text { Difference } \\
\text { (g/dl) }\end{array}$ \\
\hline Group Size (n) & 51 & 51 & \\
\hline Average (X) & $11.94^{\mathrm{a}}$ & $10.14^{\mathrm{b}}$ & 1.8 \\
\hline Typical Error (TE) & 0.13 & 0.17 & \\
\hline
\end{tabular}


Vaginal childbirth is an event where less blood is lost, a maximum of $500 \mathrm{ml}$, therefore it is expected that the difference found will be less than high birth, in our study, it found hemoglobin of the third trimester of pregnancy at 11.90, and $10.65 \mathrm{~g} / \mathrm{dl}$ in the immediate puerperium, while Atero [25] finds higher figures than the study presented, during the third trimester registering $12.87 \pm 1.16 \mathrm{~g} / \mathrm{dl}$ and it was $11.75 \pm$ $1.67 \mathrm{~g} / \mathrm{dl}$ in the immediate puerperium, however Ayllon, et al [26] in 1989 at the Maternal Perinatal Institute of Lima found lower prepartum figures $10.89 \pm 1.57 \mathrm{gr} \%$ and it was $9.95 \pm$ $1.59 \mathrm{gr} \%$ in the postpartum. Difference that makes think that before there was probably more anemia in the immediate puerperium. The difference found between hemoglobin in the third trimester and the puerperium is statistically significant with a p value of 0.05 . and it was $1.25 \mathrm{~g} / \mathrm{dl}$ and it would be located in the 50th percentile of Rubio's table [11] which means that the blood loss is within the physiological parameters.

High birth costs the mother more blood, it is calculated in $1000 \mathrm{ml}$, which demands that the mother must be prepared so that the blood loss does not lead to morbid states, however, prepartum hemoglobin of $11.94 \mathrm{~g} / \mathrm{dl}$ has been found, and in the postpartum it was $10.14 \mathrm{~g} / \mathrm{dl}$, the difference being $1.8 \mathrm{~g} / \mathrm{dl}$, higher in relation to vaginal birth $1.25 \mathrm{~g} / \mathrm{dl}$. It will be insidious in pointing out that pregnant women have to be prepared to face the process of childbirth and other very latent eventualities. Considering that hemorrhages in childbirth or immediate postpartum continue to be the first cause of mortality, the mother's health is essential at this stage of her life so that she can provide care for the newborn and provide her with invaluable exclusive breastfeeding.

It is also mention that the high incidence of anemia in pregnant women who are treated at the Hospital san Francisco, probably due to the socio-economic and political condition of the area, pregnant women with poor prenatal care due to being highly migrant and therefore with food deficits.

\section{CONClusions}

There is a significant difference between hemoglobin in the third trimester of pregnancy $11.89 \mathrm{~g} / \mathrm{dl}$ and the immediate puerperium $10.37 \mathrm{~g} / \mathrm{dl}$, being more notorious in cesarean childbirth, the values refer to moderate anemia due to the classification of the technical norm to fight against anemia in Peru, and it would be in mild anemia according to the WHO. This indicates that pregnant women in the third trimester are not arriving with hemoglobin that can face with the physiological loss of childbirth, having a task of improving strategies so that the pregnant woman can present at least a hemoglobin of $13 \mathrm{~g} / \mathrm{dl}$ before childbirth.

\section{LIMITATIONS}

One of the main limitations is the area where the investigation was carried out, it is an area convulsed by terrorism and drug trafficking, which is why it only worked with a health center in a period of one year. Another limitation is that only hemoglobin information was collected, the results of a complete blood count would have provided more clarity for the analysis of the selected population.

\section{FUTURE WORKS}

For a future study, quantitative analyzes will be performed taking into account all the hematological markers with respect to anemia to children and pregnant women, prospectively. In addition to including other health centers comparable to the population for a more detailed analysis of the progress of pregnant women in the VRAEM area.

\section{ACKNOWLEDGMENT}

We want to thank the Universidad Nacional de Huancavelica (UNH) and the Hospital de Apoyo "San Francisco" for their support in this research.

\section{REFERENCES}

[1] J. L. Casquero-León, G. A. Valle-González, J. C. Ávila-Alegría, J. R. Paredes Salas, y L. A. P. Saona-Ugarte, «Relación entre la pérdida sanguínea estimada y la pérdida sanguínea calculada en partos por cesárea en nulíparas», Revista Peruana de Ginecología y Obstetricia, vol. 58, n.o 2, pp. 115-121, 2012.

[2] I. Gómez-Sánchez, S. Rosales, L. Agreda, A. Castillo, E. AlarcónMatutti, y C. Gutiérrez, «Nivel de hemoglobina y prevalencia de anemia en gestantes según características socio-demográficas y prenatales», Revista Peruana de Epidemiología, vol. 18, n.o 2, pp. 1-6, 2014.

[3] A. Aldo Solari, G. Caterina Solari, F. Alex Wash, G. Marcos Guerrero, y G. Omar Enríquez, «Hemorragia del postparto. Principales etiologías, su prevención, diagnóstico y tratamiento», Revista Médica Clínica Las Condes, vol. 25, n.o 6, pp. 993-1003, nov. 2014, doi: 10.1016/S07168640(14)70649-2.

[4] A. J. De La Peña Silva, R. Pérez Delgado, I. Yepes Barreto, y M. De La Peña Martínez, «¿Es útil la estimación visual en la determinación de la magnitud de la hemorragia perioperatoria?: un estudio de concordancia en anestesiólogos de hospitales de mediana y alta complejidad en Cartagena, Colombia», Revista Colombiana de Anestesiología, vol. 42, n.o 4, pp. 247-254, oct. 2014, doi: 10.1016/j.rca.2014.04.003.

[5] «Protocolos de Ginecologia | El embarazo | Aborto», Scribd. https://es.scribd.com/doc/7815670/Protocolos-de-Ginecologia (accedido mar. 12, 2020).

[6] J. L. Casquero-León, G. A. Valle-González, J. C. Ávila-Alegría, J. R. Paredes Salas, y L. A. P. Saona-Ugarte, «Relación entre la pérdida sanguínea estimada y la pérdida sanguínea calculada en partos por cesárea en nulíparas», Revista Peruana de Ginecología y Obstetricia, vol. 58, n.o 2, pp. 115-121, 2012.

[7] O. F. M. García y K. P. Rodríguez, «Estudio retrospectivo sobre concentración de hemoglobina y factores asociados a la anemia posparto en primigestantes menores de 30 años de Lima, Perú, 2010», 2017.

[8] O. Munares-García y K. Palacios-Rodríguez, «Estudio retrospectivo sobre concentración de hemoglobina y factores asociados a la anemia posparto en primigestantes menores de 30 años de Lima, Perú, 2010», Medicas UIS, vol. 30, n.o 2, pp. 37-44, ago. 2017, doi: 10.18273/revmed.v30n2-2017004.

[9] A. C. Trompetero González, E. Cristancho Mejía, W. F. Benavides Pinzón, M. Serrato, M. P. Landinéz, y J. Rojas, «Comportamiento de la concentración de hemoglobina, el hematocrito y la saturación de oxígeno en una población universitaria en Colombia a diferentes alturas», Nutrición Hospitalaria, vol. 32, n.o 5, pp. 2309-2318, nov. 2015, doi: 10.3305/nh.2015.32.5.9711.

[10] H. Sacramento y O. Panta, «Relación entre los niveles de hemoglobina durante la gestación con el peso del recién nacido en el Hospital II Chocope, ESSALUD», Revista CIENCIA Y TECNOLOGÍA, vol. 13, n.o 4, pp. 21-32, jun. 2018.

[11] J. A. Rubio-Romero, H. G. Gaitán-Duarte, y N. Rodríguez-Malagón, «Concordancia entre la estimación visual y la medición del volumen recolectado en una bolsa del sangrado intraparto en mujeres con parto normal en Bogotá, Colombia, 2006», Revista Colombiana de Obstetricia y Ginecología, vol. 59, n.o 2, pp. 92-102, 2008.

[12] A. Aldo Solari, G. Caterina Solari, F. Alex Wash, G. Marcos Guerrero, y G. Omar Enríquez, «Hemorragia del postparto. Principales etiologías, su 
prevención, diagnóstico y tratamiento», Rev Med Clin Condes, vol. 25, n.o 6, pp. 993-1003, nov. 2014, doi: 10.1016/S0716-8640(14)70649-2.

[13] I. Rached de Paol i, A. Azuaje Sánchez, y G. Henriquez Pérez, «Cambios en las variables hematológicas y bioquímicas durante la gestación en mujeres eutróficas», Anales Venezolanos de Nutrición, vol. 15, n.o 1, pp. 11-17, ene. 2002.

[14] L. C. i Roura et al., Tratado de ginecología y obstetricia. 2014.

[15] S. L. Restrepo M et al., «Evaluación Del Estado Nutricional De Mujeres Gestantes Que Participaron De Un Programa De Alimentación Y Nutrición», Revista chilena de nutrición, vol. 37, n.o 1, pp. 18-30, mar. 2010, doi: 10.4067/S0717-75182010000100002.

[16] J. R. Urdaneta Machado et al., «Anemia materna y peso al nacer en productos de embarazos a término», Revista chilena de obstetricia y ginecología, vol. 80, n.o 4, pp. 297-305, ago. 2015, doi: 10.4067/S071775262015000400004 .

[17] L. Zeng et al., «Impact of micronutrient supplementation during pregnancy on birth weight, duration of gestation, and perinatal mortality in rural western China: double blind cluster randomised controlled trial», BMJ, vol. 337, p. a2001, nov. 2008, doi: 10.1136/bmj.a2001.

[18] K. E. Castro Fonseca, «Correlación Del Nivel De Hemoglobina Pre Y Postparto Y Factores Asociados Al Cuadro Clínico De Anemia En Puérperas Atendidas En El Hospital Regional Honorio Delgado Espinoza. Arequipa, 2013», 2014.

[19] B. H. Pérez, J. A. G. Tejedor, P. M. Cepeda, y A. A. Gómez, «La edad materna como factor de riesgo obstétrico. Resultados perinatales en gestantes de edad avanzada», Progresos de obstetricia y ginecología: revista oficial de la Sociedad Española de Ginecología y Obstetricia, vol. 54, n.o 11, pp. 575-580, 2011.

[20] J. Fernández Gómez, M. L. Rodríguez Pérez, G. González de la Oliva, D. Pérez Valdez-Dapena, y L. Ortega Figueroa, «Resultados perinatales de las pacientes con anemia a la captación del embarazo (enero 2015diciembre 2016)», Revista Cubana de Obstetricia y Ginecología, vol. 43, n.o 2, pp. 1-8, jun. 2017.
[21] «Tratado de Ginecología y Obstetricia: 2 Tomos». https://www.medicapanamericana.com/Libros/Libro/4838/Tratado-deGinecologia-y-Obstetricia.html (accedido mar. 12, 2020).

[22] G. Bastidas, T. Medina, M. Báez, M. Antoima, y D. Bastidas, «Perspectivas metodológicas de la investigación en salud pública, breve mirada», Revista Peruana de Medicina Experimental y Salud Publica, vol. 35, n.o 2, pp. 317-320, abr. 2018, doi: 10.17843/rpmesp.2018.352.3352.

[23] G. F. Gonzales, V. Tapia, M. Gasco, y C. Carrillo, «Hemoglobina materna en el Perú: diferencias regionales y su asociación con resultados adversos perinatales», Revista Peruana de Medicina Experimental y Salud Publica, vol. 28, n.o 3, pp. 484-491, jul. 2011.

[24] Q. Mamani y A. Ivan, «Niveles de hemoglobina materna en el tercer trimestre del embarazo como factor de riesgo para el bajo peso al nacer en recién nacidos a término en el Hospital Regional Guillermo Díaz de la Vega enero- diciembre 2016», Universidad Nacional del Altiplano, mar. 2017, Accedido: mar. 19, 2020. [En línea]. Disponible en: http://repositorio.unap.edu.pe/handle/UNAP/3812.

[25] A. Aquice y I. Pamela, «Relación De Los Niveles De Hemoglobina, Hematocrito Y Hierro Sérico Antes Y Después Del Parto Eutócico En Gestantes Atendidas En El Servicio De Gineco-Obstetricia Del Hospital Edmundo Escomel, Arequipa 2014», Universidad Católica de Santa María - UCSM, ene. 2015, Accedido: mar. 19, 2020. [En línea]. Disponible en: https://tesis.ucsm.edu.pe:80/repositorio/handle/UCSM/ 3431.

[26] G. A. B, J. H. E, y N. L. F, «Cambios hematológicos originados por el parto eutocico», Revista Peruana de Ginecología y Obstetricia, vol. 35, n.o 9, pp. 16-20, 1989, doi: 10.31403/rpgo.v35i500. 